\title{
The Integrated Life Cycle Assessment and Optimization Approach for Automotive De-manufacturing Systems
}

\author{
Naif Abdullah Alsaadi \\ Dept. of Mechanical, Industrial and Manufacturing Engineering, Toledo University \\ 2801 W. Bancroft, Toledo, Ohio 43606, United States \\ Tel: 1-419-450-8591Ｅ-mail: Naif.Alsaadi@ rockets.utoledo.edu \\ Matthew John Franchetti \\ Dept. of Mechanical, Industrial and Manufacturing Engineering, Toledo University \\ 2801 W. Bancroft, Toledo, Ohio 43606, United States
}

Tel: 1-419-530-8051_E-mail: Matthew.Franchetti@utoledo.edu

Received: December 16, 2015 Accepted: January 4, 2016

doi:10.5296/emsd.v5i1.8724 URL: http://dx.doi.org/10.5296/emsd.v5i1.8724

\begin{abstract}
The Automotive Recycling Industry is addressing one of the biggest problems that the environment can face, the reuse and recycling of End-of-Life Vehicles (ELV). Improper disposal of wastes can create a big problem to the environment. The purpose of this paper is to use the Integrated Life-Cycle Assessment (LCA) and Optimization Approach for Automotive De-manufacturing Systems with the aim of to finding out the most efficient and effective method that can be used to improve global ELV recycling. The United Nations Environment Program (UNEP) defines life cycle assessment is a tool that is used for systematic evaluation of the environmental aspects of either a product or service system in the entire stages of its lifecycle. In this research, second hand material research would be used to determine the current methods used for the disposal of the ELVs. Moreover, cost metrics will be used to determine the economic value of the network. This research will look into study background, the problem statement, hypothesis of the study, objectives of the study, literature review and methodology to outline possible research criteria to draw conclusion on the research topic. The research will be very resourceful to the scientific community because it will help to find the optimal location for the centralized processing facility that will minimize cost and avoid hazard in the environment.
\end{abstract}




\section{Macrothink

Keywords: De- manufacturing, Dismantling, Shredding, ELV

\section{Background of the Study}

\subsection{Automotive Recycling}

Recycling is the practice of gathering and processing materials that are recovered from disposed or old products and turning these materials into a new product (Aljaaidi, Almohanna, $\&$ Zaid Bin Jumah, 2013). Automotive recycling is the recovering of materials from a motor vehicle that can still be reused and recycled. Its main purpose is to harvest all automotive parts to reuse and salvage the remaining materials and recycle them to make new products that can be used in producing basic materials like plastic, steel, aluminium, copper and brass (Alliance of Automotive Manufacturers, 2010). The so-called ends of life vehicles (ELVs) are recycled into new vehicles. New vehicles can be made of recycled old consumer products and vice versa, old vehicles can be turned to new consumer products. New technology had made an opportunity to reuse and recycle material contents from the old vehicles. There is an estimate of $86 \%$ material recovery in a vehicle in the United States (Alliance of Automotive Manufacturers, 2010). Cars can be considered as most recycled consumer product. Recycling Rates 2010 show that vehicles recycling rates are over 95 percent (Alliance of Automotive Manufacturers, 2010) as shown in Figure 1. The difference between recovery and recycling rate is that recovery rate entails reclaiming used parts and materials and delivering them to a processing mill. While recycling rate refers to the level of reprocessing the recovered parts and materials, and it happens when a product has completed its original function where it is reprocessed and converted into useful new material.

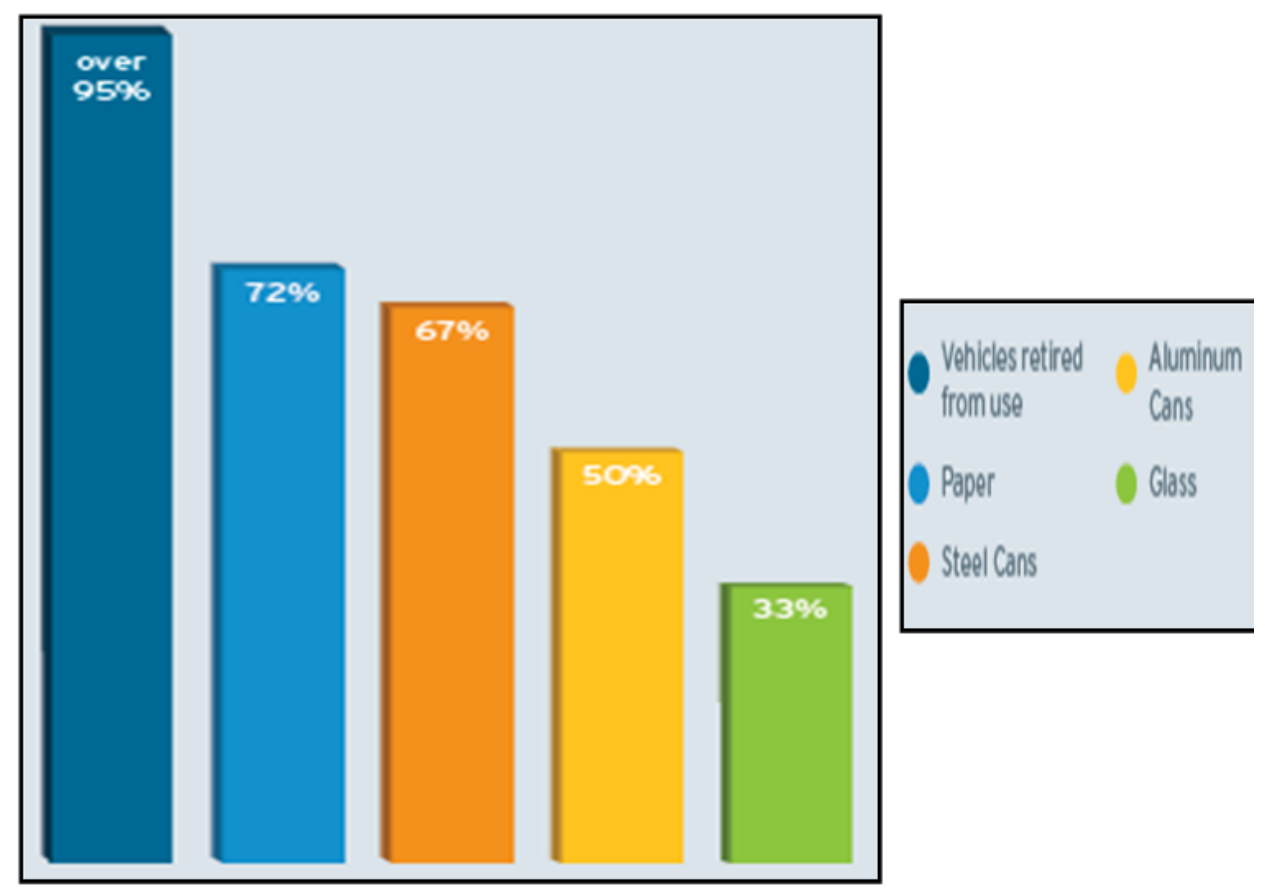

Figure 1. The recycling rates of autos in the year 2010 in comparison to other commonly used materials and parts (Alliance of Automotive Manufacturers, 2010) 


\section{Macrothink}

Environmental Management and Sustainable Development

ISSN 2164-7682 2016, Vol. 5, No. 1

\subsection{The Recycling Process}

Car Recycling would help reduce the amount of waste going to landfill and improve resource use. Cars can be recycled in three steps, dismantling, shredding and resource recovery (US Environmental Protection Agency, 2012). Figure 2 shows the process on how the vehicle is retrieved from the consumer down to the resale of parts, recycling of parts and landfill (International Specialized Skills Institute, 2009). The diagram explains how the recycling process starts.

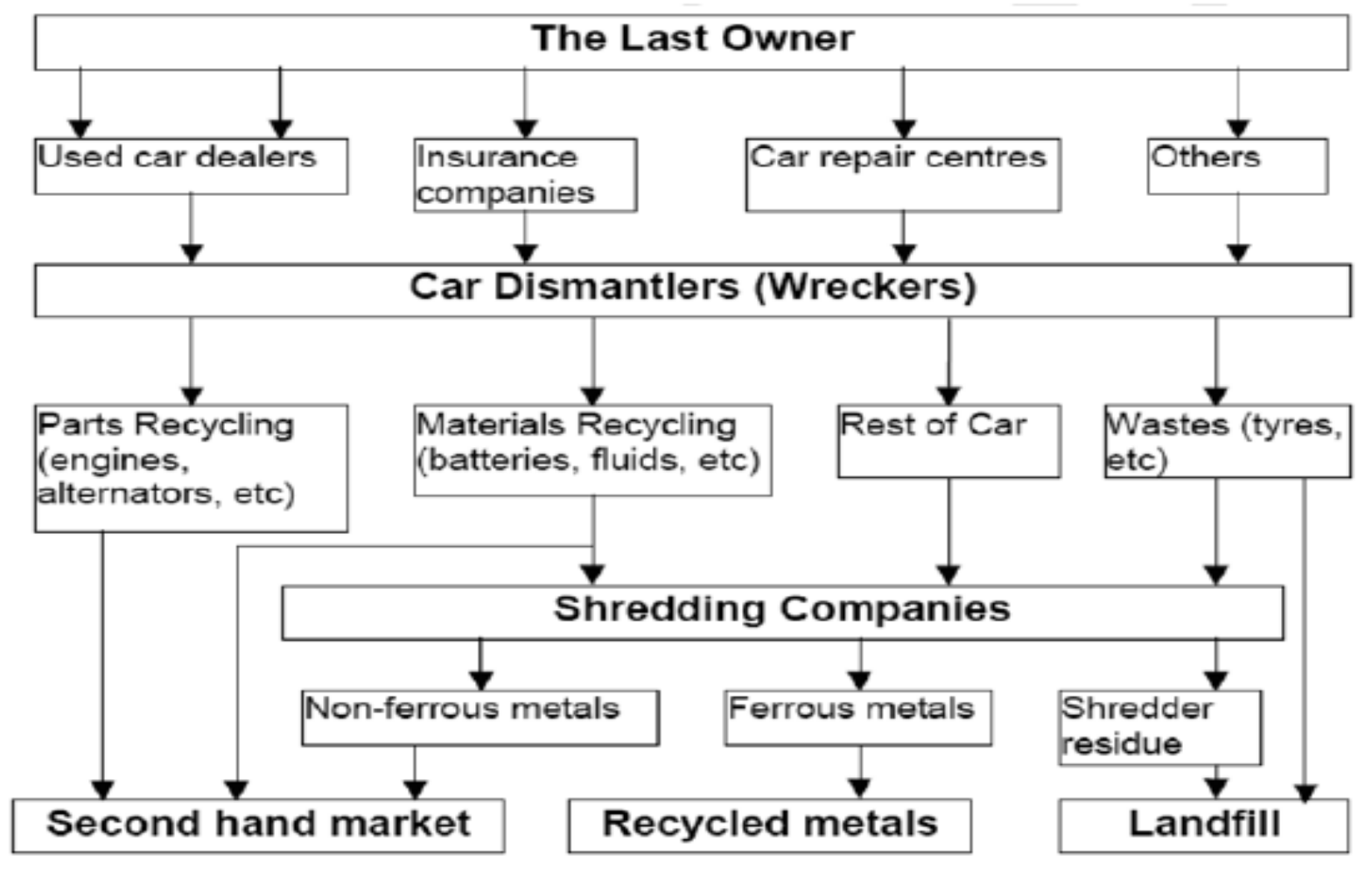

Figure 2. Automotive Recycling Process

From the last owner of the vehicle, the car is turned over by the first level in the diagram, which is the used car dealers, insurance companies, car repair centres and other sources. Then the Car Dismantlers choose what parts can still be recycled from the vehicle. There are a lot of recovered materials from the vehicle. These can be parts or fluids from the car that are being recovered and still have a profitable value in the second hand market. The parts of the car that cannot be recycled by the wreckers are flattened and go through a shredder. Sorting is done by separating the non-ferrous (non-metal), ferrous and shredder residue. Non-ferrous materials go to the second-hand market, ferrous materials are melted and recused and the residue is put in the landfill. The use of recycled scrap iron and steel reduces the use of virgin iron ore. The manufacture of recycled steel saves $74 \%$ less energy and $40 \%$ less water. It also results in $86 \%$ less air pollution, $76 \%$ less water pollution and $97 \%$ less mining wastes (Royal Automotive Club of Victoria, 2014). For every ton of new steel made of scrap, it conserves 2 $500 \mathrm{lbs}$ of iron ore, $1400 \mathrm{lbs}$ of coal and $120 \mathrm{lbs}$ of limestone (Ecoamisco, 2015). Recycled metals also reduced Greenhouse Gas (GHG) emissions. According to the Automobile 
Recycling Industry (2010) there is an approximate of 12.6 million vehicles recycled each year worldwide. Based on this estimate, GHG emissions are reduced by 30 million metric tons per year (Alliance of Automotive Manufacturers, 2010). Through this recycling process, energy is saved, natural resources are conserved, and pollution in the air, water and greenhouse emissions is reduced. Hazardous substances like lead, mercury, oil and unspent fuel can be recycled.

\subsection{Global Automotive Recycling Industry}

The recycled cars annually produce a lot of potential pollutants that can harm the environment. If these pollutants are not disposed properly by the recyclers, dire consequences can be suffered. Every year, there is an estimate of 27 million cars that reach the end of their useful life (US Environmental Protection Agency, 2012). Five million tons of shredder residue is being dumped in the landfills annually. Table 1 shows an estimate of the total potential pollutants that are being collected, reused and recycled annually.

Table 1. Estimated Amount of Materials recovered annually

\begin{tabular}{|l|l|}
\hline \multicolumn{1}{|c|}{ Fluid Recovered } & \multicolumn{1}{c|}{ Quantity Recovered } \\
\hline Gasoline and Diesel Fuel & 100.8 million gallons \\
\hline Motor Oil & 24 million gallons \\
\hline Engine Coolant & 8 million gallons \\
\hline Windshield Washer Fluid & 4.5 million gallons \\
\hline Lead Acid Batteries & $96 \%$ \\
\hline Mercury & $9000 \mathrm{lbs}$ \\
\hline
\end{tabular}

SOURCE: (Alliance of Automotive Manufacturers, 2010)

The recycling of cars is done worldwide. Government legislations have been implemented in order to address the issue. The European End-of-Life Legislation Directive 2000/53/EC is the most relevant legislative directive in the global automotive industry. The directive aims to put in heavy metal restrictions, recycling and recovery, recycled content usage and vehicle end of life take back schemes (International Specialized Skills Institute, 2009). This legislation aims to recover at least $85 \%$ of the materials from the vehicle. An amendment on the directive was also put in place wherein the vehicles may only be sold in the market if the materials are $85 \%$ (minimum) reusable or recyclable by mass. Other directives worldwide include the 2002 Japanese Automobile Recycling Law (Japan Automobile Manufacturers Association, 2002), 2008 South Korean regulation for reuse, recycle and recover hazardous substances (South Korea's waste management policies, 2015), 2008 Taiwan's ELV voluntary agreement and 2010 China which launched a technical standard. This standard is a combination of the European and Japanese Legislation. These policies create an importance to the use of recycled materials for new vehicles as well as proper disposal of materials recovered from it. In addition, they also make sure that the new vehicles in the market would be designed to have a minimal impact to the environment. 


\section{Problem Statement and Research Hypothesis}

The number of ELVs is increasing every year and this needs to be addressed in a manner with consideration to financial feasibility and its environmental impact worldwide. The automobiles consist of different materials and as such, different types of recycling facilities must be covered to ensure that good recovery of materials is done.

This research aims to determine a particular approach in order to optimize the materials recovered and minimize the cost of processing of the automobiles being recycled. The statement of the problem is to find out if an optimized automobile de-manufacturing network that is economically and environmentally beneficial to the current disposal methods can be established

The research seeks to determine the effectiveness and efficiency of an integrated vehicle recycling systems. There are a number of questions that the project seeks to answer. Some of the questions that are expected to be answered by the project include the following;

- What are the environmental impacts that are caused by the current methods of vehicle disposal?

- What are the existing legal policies that govern the disposal of ELVs?

- What are the existing disposal mechanisms that are involved in developing an integrated vehicle recycling facility?

- What are the optimal processing mechanisms that can be used to dispose ELVs?

- What are the main raw materials that can be obtained from processed ELVs?

- What are the factors that should be taken into account for cost computation of dismantling and shredding ELVs?

These questions will be answered by the project. The project looks forward to determine the overall benefits that can be accrued from the development of an integrated vehicle recycling facilities.

\section{Review of Related Literature}

This part of the paper shows the relevant research materials that the researchers had gathered to get more information on the problem at hand. This is also a way to answer some of the objectives of the study and provide ideas to solve the problem under study.

\subsection{Reverse Logistics}

Manufacturing industries are used to doing forward logistics most of the time. Raw materials are gathered and processed in order to create new products for the consumers. Logistics enters from Raw Materials to manufacturing until it reaches the end consumer. However, the same is not true for recycling materials. In recycling, reverse logistics is used in order to recover raw materials from the product. Reverse logistics is concerned about all procedures or methods associated from product returns, maintenance and repairs, recycling and dismantling for products and materials (Adaptalift Hyster, 2013). Recycling companies use reverse logistics in order to have raw materials for their production. Figure 3 shows the diagram on how reverse logistics work. 


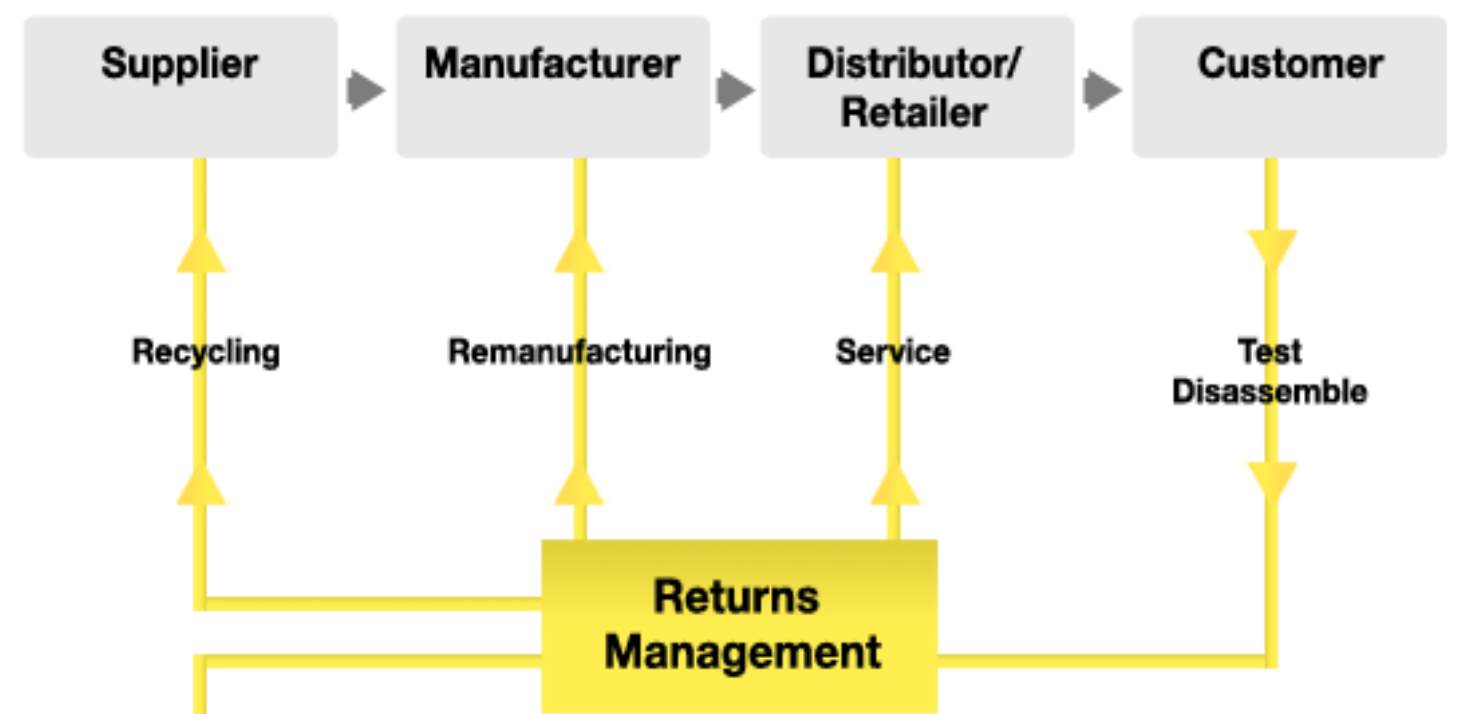

Dispose

Figure 3. Reverse Logistics flow (Adaptalift Hyster, 2013)

All activities in the Reverse Logistics System incur costs. These must be considered in the design of the model for the system. Activities that incur cost in the system are as follows: transportation, product collection, disposal of products, remanufacturing and recycling of the products and the labor costs for the retrieval of the product (Sanket, 2009).

\subsection{ELV Recycling}

Automotive Recycling has three primary areas of recovery for reverse logistics. First, the working components, these are sold as what they are to the market. Second, recoverable components or auto parts which are refurbished before they are sold in the market and lastly, unrecoverable components, these materials are reclaimed through crushing and shredding.

\subsubsection{Parts and Suppliers De-manufacturing}

An article from Holden Australia had cited the procedure on to how the vehicles are recycled in general. Batteries are first disconnected. After the disconnection, all fluids must be drained out of the car. Pyrotechnic devices are also removed; these devices include airbags. It is advisable to remove them because pyrotechnic devices contain ingredient that represent explosion hazards (Autoparts Recycle Association of Australiar; Greenfleet; Holden, 2014). There is a standard initial handling procedure that automotive companies follow during the de-manufacturing process. Table 2 shows a list of manufacturers and their procedures in ELV recycling. These 3 companies were chosen because information is readily available to the public. 
Table 2. Standard handling procedure of recycling per manufacturer

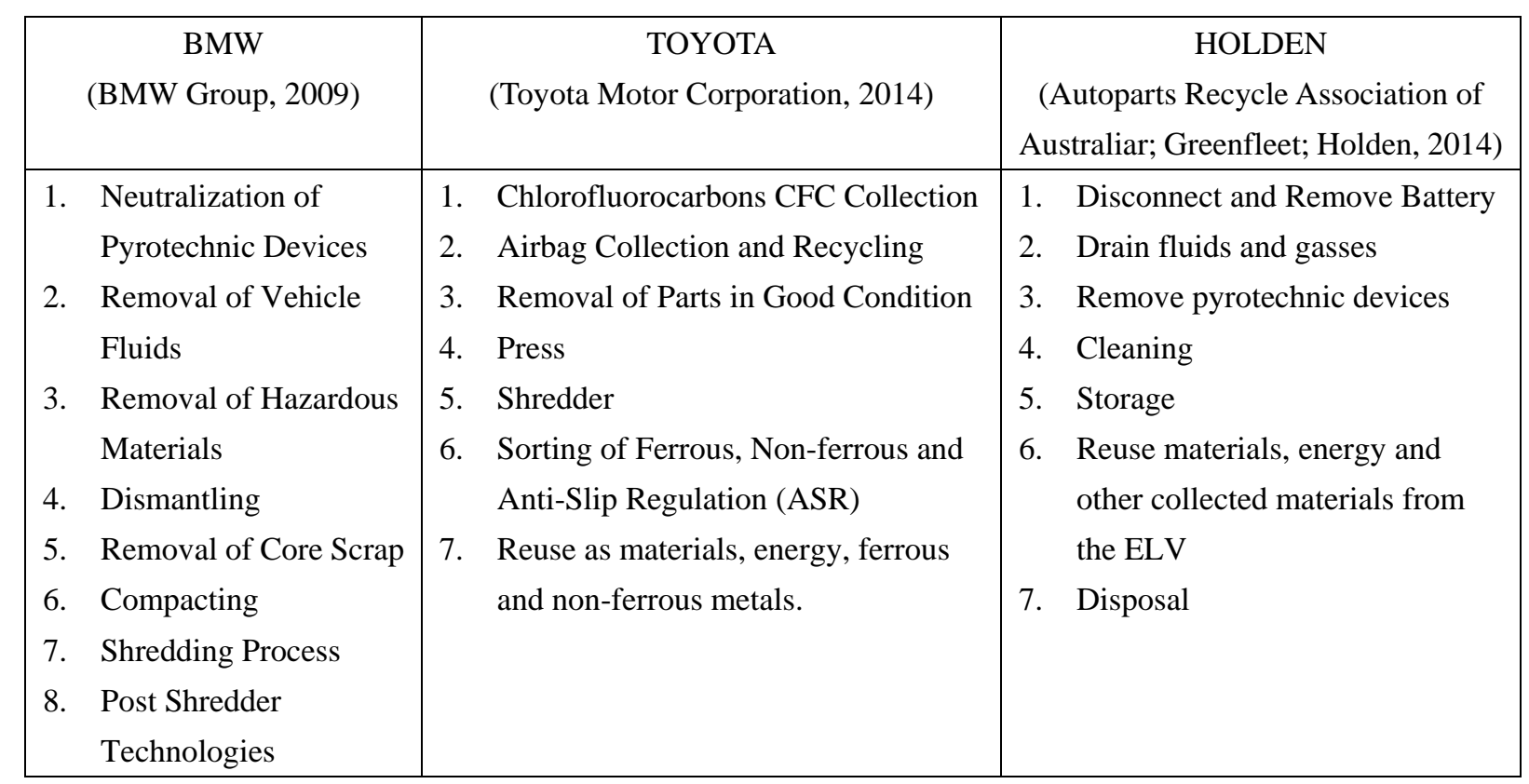

Each manufacturer has a different way of recycling materials. However, all of the above is focused on removing the hazardous materials inside the car. Appendix B is a list of Recycling Auto parts that could be removed from the car. The list contains the component of the vehicle, the materials used to manufacture the component, the method of dismantling, the storage area where these components must be stored in, disposal of the said component and safety precautions. This information is provided in the article of Holden Australia (Autoparts Recycle Association of Australia; Greenfleet; Holden, 2014).

The following is a brief description of the process, as soon as the vehicle is dropped off,

- Hazardous materials such as the CFC and the airbags are removed.

- Parts that are in good condition are removed;

- Parts are sorted according to reusable ones, ferrous materials and non-ferrous materials.

- After this recovery, the cars are pressed and go through the shredder.

- The shredded parts would be classified as either ferrous or non-ferrous and shredder residue.

Ferrous and non-ferrous metals are melted and reused; ASR or shredder residue is either used as a material or as energy. Figure 5 shows the after processing of the ELV from the shredder to the ASR Recycling Plant (Toyota Motor Corporation, 2014). 


\section{Macrothink}

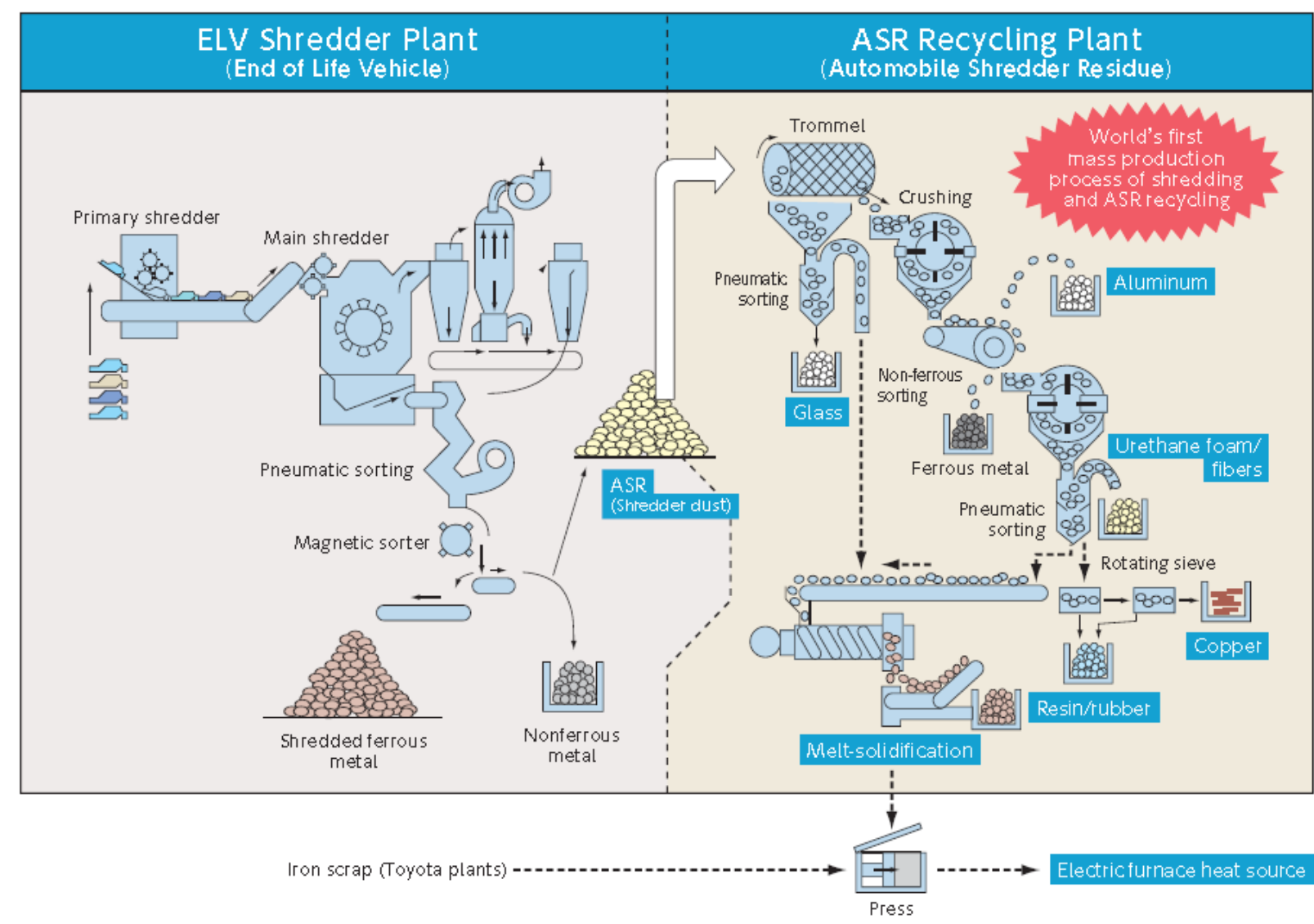

Figure 4. ASR Process after ELV Shredding

As of the moment, Toyota can recover and reuse the ELV materials $99 \%$ its body weight (Toyota Motor Corporation, 2014), in Holden Australia the ELV materials recovered is around $75 \%$ and $25 \%$ is dumped in the landfill (Autoparts Recycle Association of Australia; Greenfleet; Holden, 2014) and BMW is expected to recover at least $85 \%$ of its materials (BMW Group, 2009). However, Europe has a directive that recovery target level must reach 95\% by this year, 2015 (European Commission, 2005).

\subsubsection{Cost of Recycling}

Nowadays, cars are created to be more fuel efficient and to do that lighter materials are chosen. The metallic fraction of the automobiles is reduced resulting to higher components of polymers, fabrics and glass. There is a high demand for metal scrap but for the other materials there is no demand in the form where it emerges from the shredder. Disposal of the materials are done through landfills. If the cost of the landfill is low, then the cost of operating the shredder is just a fraction of the cost amount in operating the shredder. However, if the landfill cost is high, the cost in operating the shredder may not be able to cover the costs (Field, 1993). There are five factors that a dismantler must take into account for cost computation. The following factors are

- The cost of getting the ELV (End-of-Life-Vehicle)

- The cost of extraction, storage and distribution of parts that can be sold, 
- The price of the used parts that can be sold,

- The cost of extracting and removing the parts that the shredder does not need in the stripped car, and

- The price of the stripped car that would be sold to the shredder.

Given that the dismantler and the shredder are not in the same company, then there are also five factors to consider in shredding the vehicle. These includes the

- The cost of the hulk to be obtained,

- The operating cost of the shredder and the ferrous separator,

- Disposal cost of the automotive shredder residue,

- The asking price that the shredder gets from the steel processed and lastly

- The asking price for the mixed non-ferrous metal blend (Field, 1993).

A lot of researches had been done using Reverse Logistics as a tool to formulate mathematical models to support the recovery plan and disassembly sequence in automobiles.

Technical cost models of ELV processing operators were developed and the results show that removing of $14 \%$ of the ELV mass results in a recycling rate of $80 \%$ (Zarei, Mansour, Kashan, \& Karimi, 2010). A simulated model to examine the effects of future changes in the vehicle was developed. The model yielded that the recycling target of $95 \%$ by the year 2015 would be unreachable unless changes would be done in vehicle material composition (Zarei, Mansour, Kashan, \& Karimi, 2010).

The conceptual model was developed by Zarei, Mansour, Kashan, and Karimi and had included the production of new vehicles and recovery of used ones. In this model, it was assumed that the whole network is conducted by a vehicle manufacturer. Distribution-collection centres are assumed. Collection of ELVs is assigned to these distribution centres. The model developed was to minimize the costs of setting up network and raw materials flow between different facilities (Zarei, Mansour, Kashan, \& Karimi, 2010).

Elwany, Fors, Harraz, \& Galal (2007) in their article "Reverse logistics network design" reviewed different review of models and solution techniques were reviewed in an article for reverse logistics. Four different modelling technique classifications were identified in the study. These are the following:

\section{i. Classification based on order type of flow}

There are two models consider; and these are the forward and reverse networks. These two models two different entities and are designed in succession. The other approach in this type is the combination of these two flow types in the design process.

\section{ii. Classification according to model type}

These models are based on the type of programming used. Model can be a mixed integer linear programming or mixed integer non-linear programming. Mixed integer models represent integer variables such as facilities and continuous variables; they also represent the 
amount of material flow between the different facility types. The Mixed integer non-linear programming accounts for the aspects discussed in mixed integer models combined with time.

\section{iii. Classification according to objective function}

The objective function classifies the models according to the numbers and type of model. The model can answer one objective or multiple objectives depending on the researcher. Most objective function models are considered to have a location allocation problem with a single objective either to minimize cost or maximize revenue.

iv. Uncertainty in Reverse Logistics

Some models used for reverse logistics incorporated uncertainty variables in their models. There are four approaches that can incorporate uncertainty in the models, and these are:

- Sensitivity analysis, this is used to determine how the output of the model will be changed if uncertainties are present in the model inputs.

- Scenario Based Approaches, this is an extension of the sensitivity analysis. The model is iterated until an individual solution that performs best is arrived at.

- Robust Optimization, the uncertainty is represented through different scenarios, the model aims to minimize the measure of deviation of the resolution from the objective function value from the best solution achieved for each scenarios created.

- Stochastic Programming, this is a mathematical programming process that deals with stochastic elements in the data. Probability distributions are used as the main element in the model.

The program applied in network design problem is considered as the recourse type. There are two stages of approach to this type of model. Stage 1 determines the set of decision variables and Stage 2 determines the recourse action after a random event has taken value. The action in stage 2 makes sure that the constraints in the models are in place.

\subsection{Automotive Recycling Association}

A lot of countries around the world are conscious on the growing problem of vehicle recycling. In order to address the problem, these countries had joined movements such as the Automotive Recyclers Association in order to learn and share ideas about ELV recycling. The association was founded in 1943, and has a global presence being an international trade association representing the automotive industry with a focus on efficient removal and reuse of automotive parts. The following regions and countries have different legislations and directives to follow. Each point would be explained through the legislation, recovery rate and the law directives. The regions and countries have been chosen because they have the most elaborate legislations and directives regarding ELVs. 
Table 3. Country/Place and the directives or laws regarding ELVs

\begin{tabular}{|c|c|c|}
\hline \multirow{3}{*}{$\begin{array}{l}\text { EUROPE } \\
\text { (Directive } \\
\text { 2000/53/EC, 2005) }\end{array}$} & Law/Legislation & Directive 2000/53/EC \\
\hline & Recovery Rates & $\begin{array}{l}85-95 \% \text { by } 2015 \\
5 \% \text { of ASR will go to landfill }\end{array}$ \\
\hline & The Law & $\begin{array}{l}\text { - Manufacturers must reduce the use of hazardous materials when } \\
\text { designing or producing a vehicle } \\
\text { - } \\
\text { - } \\
\text { - } \\
\text { - Collection of ELVize on increasing the use of recycled materials } \\
\text { implemented } \\
\text { - } \quad \text { permits must be obtained by dismantlers }\end{array}$ \\
\hline \multirow{3}{*}{$\begin{array}{l}\text { JAPAN } \\
\text { (MInistry of } \\
\text { Economy, Trade and } \\
\text { Industry, 2005) }\end{array}$} & Law/Legislation & End of Life Vehicle Recycling Law \\
\hline & Recovery Rates & $85-95 \%$ by 2015 \\
\hline & The Law & $\begin{array}{l}\text { - A network must be established between car owners, ELV } \\
\text { collecting business, manufacturers and car importers to recycle } \\
\text { ELVs properly } \\
\text { - Fees shall be paid upon purchasing new cars for those who } \\
\text { purchase new cars from January 2005, the case of disposing of } \\
\text { cars without undergoing a periodic inspection, fees shall be paid } \\
\text { to ELV - collecting businesses when ELVs are handed over to } \\
\text { them }\end{array}$ \\
\hline \multirow{3}{*}{$\begin{array}{l}\text { KOREA } \\
\text { (RSJ Technical } \\
\text { Consulting, 2007) }\end{array}$} & Law/Legislation & $\begin{array}{l}\text { Act for Resource Recycling of Electrical and Electronic } \\
\text { Equipment and Vehicles }\end{array}$ \\
\hline & Recovery Rates & $85-95 \%$ by 2015 \\
\hline & The Law & $\begin{array}{l}\text { - Restriction on the use of hazardous materials } \\
\text { - Improvement of materials and structure in products for easy } \\
\text { recycling } \\
\text { - Separate collection of waste products for easy recycling } \\
\text { - Manufacturers or importers of vehicles receive an annual } \\
\text { - } \text { recycling rate by joining a vehicle association } \\
\text { Establishment of Recycling Information Network }\end{array}$ \\
\hline \multirow{3}{*}{$\begin{array}{l}\text { Canada } \\
\text { (Automotive } \\
\text { Recyclers } \\
\text { Canada, 2011) of }\end{array}$} & Law/Legislation & Canadian Auto recyclers Environmental Code \\
\hline & Recovery Rates & $94 \%$ recovery rate \\
\hline & The Law & $\begin{array}{l}\text { - Dismantling and Recycling of vehicles is more environmentally } \\
\text { friendly } \\
\text { - Manufacturers are mandated to produce new vehicles with a view } \\
\text { to increased recyclability }\end{array}$ \\
\hline \multirow{2}{*}{$\begin{array}{l}\text { UNITED STATES } \\
\text { (Staudinger \& \& }\end{array}$} & Law/Directive & Automobile Recycling Study Act of 1991 (HR 3369). \\
\hline & Recovery Rate & $95 \%$ recovery rate \\
\hline
\end{tabular}




\begin{tabular}{|l|l|l|}
\hline Keoleian, 2001) & The Law & $\begin{array}{l}\text { Identify potential problems in recycling and develop new } \\
\text { solutions to the identified problems }\end{array}$ \\
$\bullet \begin{array}{l}\text { Recyclability must be incorporated in the plans and designs of } \\
\text { newly manufactured autos }\end{array}$ \\
$\begin{array}{l}\text { Determine possible substitutes to hazardous substances used in } \\
\text { vehicles. }\end{array}$ \\
$\begin{array}{l}\text { Create design standards for autos that would result in phasing out } \\
\text { of hazardous and non-recyclable materials } \\
\text { Examine methods for creating more recyclable plastics for use in } \\
\text { autos }\end{array}$
\end{tabular}

In order for these laws to take into effect, the main focus of recycling must be with the producer which can either be the vehicle manufacturer or the professional importer of the vehicle. The link from supplier of the cars to the collector, dismantler and shredder is necessary in order to meet all the regulations directed by law (Kanari, Pineau, \& Shallari, 2003).

\subsection{Summary of Review of Related Literature}

Reverse Logistics is the control process flow of raw materials, inventory and finished goods from the end user to the point of origin to recapture value or disposed waste properly. Reverse Logistics is also the foundation of the mathematical models formulated for ELV network design. Reverse Logistics System for Automotive Industry is usually designed in order to minimize cost and optimize materials recovery. Different models and techniques were formulated by past researchers in order to determine the optimal solution for the problem at hand. Reverse Logistics is the basis of the models being created by the previous researchers. Different techniques include Mixed Integer Programming, Non-Linear Programming, and Order type of flow models, Objective function models, and models that consider uncertainty. In this study, legislative orders, processes and recycled materials are taken into consideration to determine the feasibility of creating a new vehicle recycling facility.

In dealing with ELV recycling, one must study the different parts that auto manufacturers disposes and sells in the market so as to determine the different costs and profit around the system. Each car manufacturer deals with a different kind of approach in ELV recycling. Toyota, BMW and Holden are only examples of manufacturers who does ELV recycling. These car manufacturers together with brilliant minds in the world and different recycling associations had joined in order to create the Automotive Recycling Association (ARA). Since each parts of the world deal with ELV differently, the ARA can be a good way to share ideas and make the recycling of vehicles in each country more efficiently done. Different laws also apply in each country but the most effective law that has been referenced from is the European Law, directive 2000/53/EC. Most countries and car manufacturers have adapted with this particular directive.

\section{Methodology}

This chapter deals with the research design and the methodology carried out throughout the 
study. The project puts emphasis on different methods and techniques that are known to be effective in developing an integrated vehicle recycling facility. The vehicle recycling system is also expected to improve the willingness of vehicle owners toward adopting good disposal mechanisms of ELVs. It is expected to establish recycling facilities at different regions in the world. These facilities will be established close to ELVs prone regions. The project will also focus partly on research that has been done in the past in relation to the disposal techniques of ELVs hence is based on the secondary source of data. This implies that the project will involve a wide scope in deriving the solution to the problem of environmental pollution that is realized from poor disposal mechanisms of ELVs. Both qualitative and quantitative approaches will be involved in deriving a concrete solution. The following diagram can be used to illustrate the key steps that will be involved in the design of an effective development methodology. Both the research and effective historical practices have been incorporated in the methodology.

Before discussing the methodology paradigm, it is important to understand the advantages and disadvantages of vehicle recycling facility before delving into the steps that should be taken in the methodology.

Advantages of vehicle recycling facilities:

There are many benefits that can be realized from the use of vehicle recycling. To start with, a vehicle recycling system is expected to reduce the wastes that are disposed to the environment as a result of the ELVs. The ELV landfills are expected to reduce with the implementation of the project. This implies that the overall negative impacts that are realized on the environment as a result of poor disposal methods of ELVs will reduce significantly.

The vehicle recycling system is also expected to improve the willingness of vehicle owners toward adopting good disposal mechanisms of ELVs. It is expected to establish recycling facilities at different regions in the world. These facilities will be established close to ELVs prone regions.

The mechanism proposed in this project is also expected to earn some income to vehicle owners. Vehicle owners are expected to be paid scrap value of the vehicle they are disposing. Additionally, the facilities will also create job opportunities all over the world. This will directly improve the living standards of people working in such facilities (Mathieux \& Brissaud, 2010) .

The adoption of vehicle recycling facilities is expected to create a new channel of standardized scrap metals and spare parts. The spare parts that will be retrieved from ELVs will be passed through thorough assessment to ascertain their operational standards. This is considered to boost the automotive industry with availability of spare parts that have extended life. The scrap metal obtained from the facilities will also be used as raw materials in other different industries (Hatayama, Daigo, Matsuno, \& Adachi, 2012).

Disadvantages of vehicle recycling facilities:

The only disadvantage that is associated with this project is the reduction in the prices of 
spare parts. The establishment of vehicle recycling facilities will introduce many spare parts which will be readily available in the market. This will definitely reduce the overall price and demand for the spare parts.

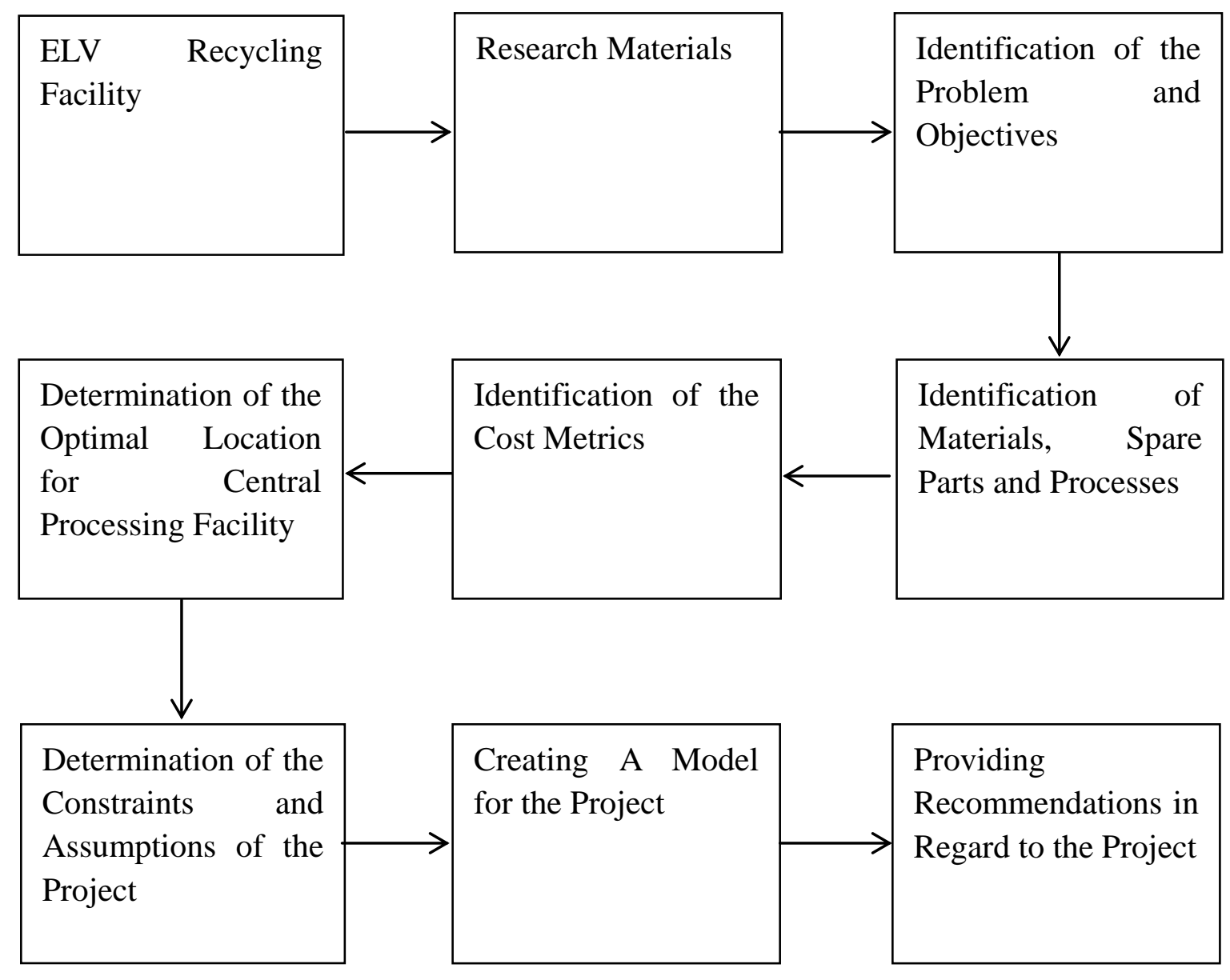

Figure 5. Methodology Paradigm

\subsection{ELV Recycling Facility}

The researchers have determined the industry of interest as ELV recycling facility. The recycling of ELVs is of interest to the researcher because it poses a threat to the environment. Aside from the threat to the environment, a number of materials can be recovered from vehicle recycling. This facility can save a lot of energy and resources from the environment and as such is a good topic of interest.

\subsection{Research Materials}

The methodology for this project involves research in the internet and other related materials from online libraries. A section of the project will be developed on the basis of the information received from already existing recycling facilities. The following table can be used to summarize the methodology that will be employed in the study. 
Table 5. Concepts are derived from other related materials

\begin{tabular}{|c|c|c|}
\hline Concept & Description & Source \\
\hline \multirow[t]{2}{*}{$\begin{array}{l}\text { Determination of Effective } \\
\text { Network for ELV Recycling }\end{array}$} & 1. ELV Recycling & $\begin{array}{l}\text { - } \\
\text { Manufliance of Automotive } \\
\text { - } \quad \text { (US Environmental Protection } \\
\text { Agency, 2012) }\end{array}$ \\
\hline & 2. Reverse Logistics & $\begin{array}{ll}\text { - } & \text { (Adaptalift Hyster, 2013) } \\
\text { - } & \text { (Sanket, 2009) }\end{array}$ \\
\hline \multirow{3}{*}{$\begin{array}{l}\text { Identification of Process and } \\
\text { Materials }\end{array}$} & 1. Typical ELV Process & (Zhaoanjian \& Yang, 2014) \\
\hline & $\begin{array}{l}\text { 2. Parts and Suppliers } \\
\text { De-manufacturing }\end{array}$ & 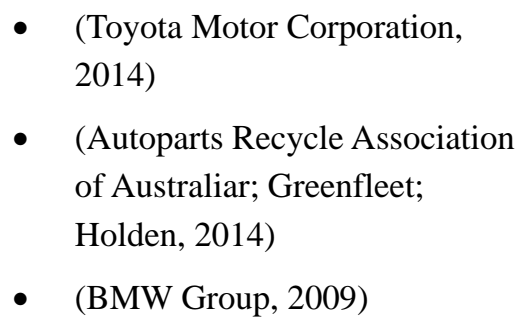 \\
\hline & $\begin{array}{l}\text { 3. Factors that must take into account } \\
\text { for ELV's Recycling Cost }\end{array}$ & (Field, 1993) \\
\hline \multirow[t]{5}{*}{$\begin{array}{l}\text { Identification of the } \\
\text { constraints and laws }\end{array}$} & $\begin{array}{l}\text { 1. EUROPE } \\
\text { Directive 2000/53/EC }\end{array}$ & (Kanari, Pineau, \& Shallari, 2003) \\
\hline & $\begin{array}{l}\text { 2. JAPAN } \\
\text { End of Life Vehicle Recycling Law }\end{array}$ & $\begin{array}{l}\text { (MInistry of Economy, Trade and } \\
\text { Industry, 2005) }\end{array}$ \\
\hline & $\begin{array}{l}\text { 3. KOREA } \\
\text { Act for Resource Recycling of } \\
\text { Electrical and Electronic Equipment } \\
\text { and Vehicles }\end{array}$ & (RSJ Technical Consulting, 2007) \\
\hline & $\begin{array}{l}\text { 4. Canada } \\
\text { Canadian Auto } \\
\text { recyclers Environmental Code }\end{array}$ & $\begin{array}{l}\text { (Automotive Recyclers of Canada, } \\
\text { 2011) }\end{array}$ \\
\hline & $\begin{array}{l}\text { 5. UNITED STATES } \\
\text { Automobile Recycling Study Act of } \\
\text { 1991 (HR 3369). }\end{array}$ & (Staudinger \& Keoleian, 2001) \\
\hline \multirow[t]{3}{*}{ Mathematical Models } & $\begin{array}{l}\text { 1. Technical Cost model of ELV } \\
\text { Processing Operators }\end{array}$ & (Zhaoanjian \& Yang, 2014) \\
\hline & $\begin{array}{l}\text { 2. Conceptual Model of a network } \\
\text { handled by vehicle manufacturer }\end{array}$ & $\begin{array}{l}\text { (Zarei, Mansour, Kashan, \& Karimi, } \\
\text { 2010) }\end{array}$ \\
\hline & $\begin{array}{l}\text { 3. Four Modelling Technique } \\
\text { classification }\end{array}$ & $\begin{array}{l}\text { (Elwany, Fors, Harraz, \& Galal, } \\
\text { 2007) }\end{array}$ \\
\hline
\end{tabular}




\subsection{Identification of the Problem and Objectives of the Project}

The problem and objectives of the project were identified based on the research materials gathered from the industry statistic and second hand information materials. The objectives of the study were based on how the solution can be arrived at to solve the problem of the study.

\subsection{Identification of Materials, Spare Parts and Processes}

This stage involves determination of the materials and processes involved in the vehicle recycling network. It will seek to identify different raw materials that can be retrieved from the ELVs. It will also determine the operational standards of spare parts obtained from ELVs. Table 5, shows how the raw materials, spare parts and the processes can be determined.

Table 5. Identification of Materials, Spare Parts and Processes

\begin{tabular}{|c|c|c|}
\hline DETAILS & MATERIALS & SOURCE \\
\hline \multirow[t]{4}{*}{$\begin{array}{l}\text { Materials and } \\
\text { Spare Parts }\end{array}$} & Recycled Vehicle Fluids & $\begin{array}{l}\text { Check local directory for end users of Vehicle Fluids (Yellow } \\
\text { Pages, interview with local wreckers) }\end{array}$ \\
\hline & $\begin{array}{l}\text { Hazardous } \quad \text { Materials } \\
\text { from ELV }\end{array}$ & $\begin{array}{l}\text { Check with local government departments if there are any special } \\
\text { procedures in dealing with hazardous materials from ELV (Online } \\
\text { and Interview with local government units) }\end{array}$ \\
\hline & $\begin{array}{l}\text { Recycled Spare Parts } \\
\text { from ELV }\end{array}$ & $\begin{array}{l}\text { Check local directory for end users of recycled Spare Parts } \\
\text { (interview with local wreckers) }\end{array}$ \\
\hline & $\begin{array}{lr}\text { ELV Car } & \text { Chassis, } \\
\text { Compacted Scrap Metal } \\
\text { Shredded } & \text { Materials } \\
\text { (Ferrous } & \text { and } \\
\text { Non-ferrous) } & \end{array}$ & $\begin{array}{l}\text { Check local directory for shredders and compacting facilities in the } \\
\text { area. It would be helpful to ask local car dealers if they are } \\
\text { acquiring ELV from customers and how they deal with this }\end{array}$ \\
\hline \multirow[t]{6}{*}{ Process } & Acquiring ELV & $\begin{array}{l}\text { Ask Car dealers if they are acquiring ELV, Check local directory } \\
\text { for car junk yards on how they acquire ELV }\end{array}$ \\
\hline & $\begin{array}{l}\text { Neutralization } \\
\text { Pyrotechnic Devices }\end{array}$ & $\begin{array}{l}\text { Inquire about this with car dealers, local car wreckers and car junk } \\
\text { yard }\end{array}$ \\
\hline & $\begin{array}{l}\text { Removal of Vehicle } \\
\text { Fluids }\end{array}$ & $\begin{array}{l}\text { Inquire about this with car dealers, local car wreckers and car junk } \\
\text { yard }\end{array}$ \\
\hline & $\begin{array}{l}\text { Removal of Hazardous } \\
\text { Materials }\end{array}$ & $\begin{array}{l}\text { Inquire about this with car dealers, local car wreckers and car junk } \\
\text { yard }\end{array}$ \\
\hline & Dismantling & $\begin{array}{l}\text { Inquire about this with car dealers, local car wreckers and car junk } \\
\text { yard }\end{array}$ \\
\hline & Removal of Core Scrap & Inquire about this with car dealers, local car wreckers and car junk \\
\hline
\end{tabular}




\begin{tabular}{|l|l|l|}
\hline \multicolumn{2}{|l|}{} & yard \\
\cline { 2 - 3 } & Compacting & $\begin{array}{l}\text { Inquire about this with car dealers, local car wreckers and car junk } \\
\text { yard. Research on compacting facilities for cars }\end{array}$ \\
\cline { 2 - 3 } & Shredding Process & $\begin{array}{l}\text { Inquire about this with car dealers, local car wreckers and car junk } \\
\text { yard. Research on Shredding facilities for cars }\end{array}$ \\
\cline { 2 - 3 } & $\begin{array}{l}\text { Post } \\
\text { Technologies }\end{array}$ & $\begin{array}{l}\text { Inquire about this with scrap metal dealers and shredding } \\
\text { facilities or even local waste management unit }\end{array}$ \\
\hline
\end{tabular}

\subsection{Identification of the cost metrics for vehicle recycling process.}

This stage involves determination of the costs involved in the vehicle recycling facilities. The cost associated for each process should be determined in order to create the proposed model for the project. Each cost can be used as a variable in the model formulation. It will also determine the overall benefits that are associated with the establishment of the vehicle recycling facilities. Table 6 , illustrates how the costs incurred in the vehicle recycling system can be determined.

Table 6. Possible costs incurred during the ELV recycling

\begin{tabular}{|c|c|}
\hline Cost Metric & Source \\
\hline Cost of Acquiring ELV & $\begin{array}{l}\text { Interview with car dealers (if they are } \\
\text { de-manufacturing), car wreckers, car junk yard }\end{array}$ \\
\hline $\begin{array}{l}\text { the cost of extracting, storing, and distributing the parts } \\
\text { that can be sold }\end{array}$ & Interview with car wreckers and car junkyard \\
\hline Price of Parts that can be sold & $\begin{array}{l}\text { Interview with car wreckers and spare part auto } \\
\text { resellers }\end{array}$ \\
\hline $\begin{array}{l}\text { Cost of extracting and removing the parts that the } \\
\text { shredder does not want in the stripped car }\end{array}$ & $\begin{array}{l}\text { Interview with car dealers (if they are } \\
\text { de-manufacturing), car wreckers, car junk yard }\end{array}$ \\
\hline $\begin{array}{l}\text { Price of the stripped car that would be sold to the } \\
\text { shredder }\end{array}$ & $\begin{array}{l}\text { Interview with car shredder facility, car wreckers and } \\
\text { car junk yards }\end{array}$ \\
\hline Cost of metal scrap & Interview with metal scrap dealers \\
\hline Operating cost of the shredder and ferrous separator & Interview with shredding facilities \\
\hline Disposal cost of Automotive Shredder Residue & $\begin{array}{l}\text { Interview with shredding facilities and local waste } \\
\text { management unit }\end{array}$ \\
\hline Asking Price of shredded ferrous metal blend & Interview with scrap metal dealers and shredders \\
\hline Asking Price of the mixed non-ferrous metal blend & $\begin{array}{l}\text { Interview with recyclers that deal with on-ferrous } \\
\text { metal blend }\end{array}$ \\
\hline Cost of Acquiring a new shredder & Research online and interview with shredder facilities \\
\hline Cost of acquiring a ferrous separator & Research online and interview with shredder facilities \\
\hline
\end{tabular}


4.6 Determination of the optimal location for central processing facility

Based on the review of related literature and the cost metrics identified, the researchers must determine what practices must be done and where the optimal location of a central processing facility could be established. The network will facilitate the market of the scrap metals and spare parts obtained from ELVs. It will also boost the willingness of owners in disposing their vehicles through the facility.

\subsection{Determination of the Constraints and the Assumptions of the Project}

This stage will involve determination of the establishment limits that are associated with implementation of vehicle recycling facilities. All the constraints including cost, sensitization and review of different legal parameters in different countries will be evaluated in this stage. Constraints can be something that the government had created and assumptions can be ideal conditions that the process takes place in.

\subsection{Creation of the model project}

A synthesized model will be created to establish de-manufacturing network for end-of-life vehicles. The model will constitute all the parameters that are expected to be involved in the implementation of the project and will comprise of preliminary and actual necessary operations. The mathematical model would be able to allocate material flows within the network and determine the optimum locations of the central shredding facility that can minimize the total cost related to vehicle recycling. The criteria of optimization are the cost of transportation, storage, dismantling and shredding of ELVs. The model inputs would be cost of acquiring and collecting ELV, cost of dismantling ELV, cost of compacting and shredding ELV, and transportations costs within the network. Figure 6 shows the structure of the proposed de-manufacturing network. There are direct economic and environmental contributions of this de-manufacturing network of end of life vehicles. The economic benefits include the promotion of resource efficiency as it will provide incentives for innovation not only in vehicle design, but also in the treatment of ELVs. In addition, it will lead to an improved efficiency in the treatment sector; the case study reports an improved professional and technical approach, with investments that will lead to higher operational efficiency; it will also secure its long term future. The practical contributions to the environment include an increase in the number of vehicles in the integrated vehicle recycling facility. It will also lead to an increased level in how different materials are treated. There will also be continuous improvement in the quality of the environment as the approach becomes more fully implemented. 


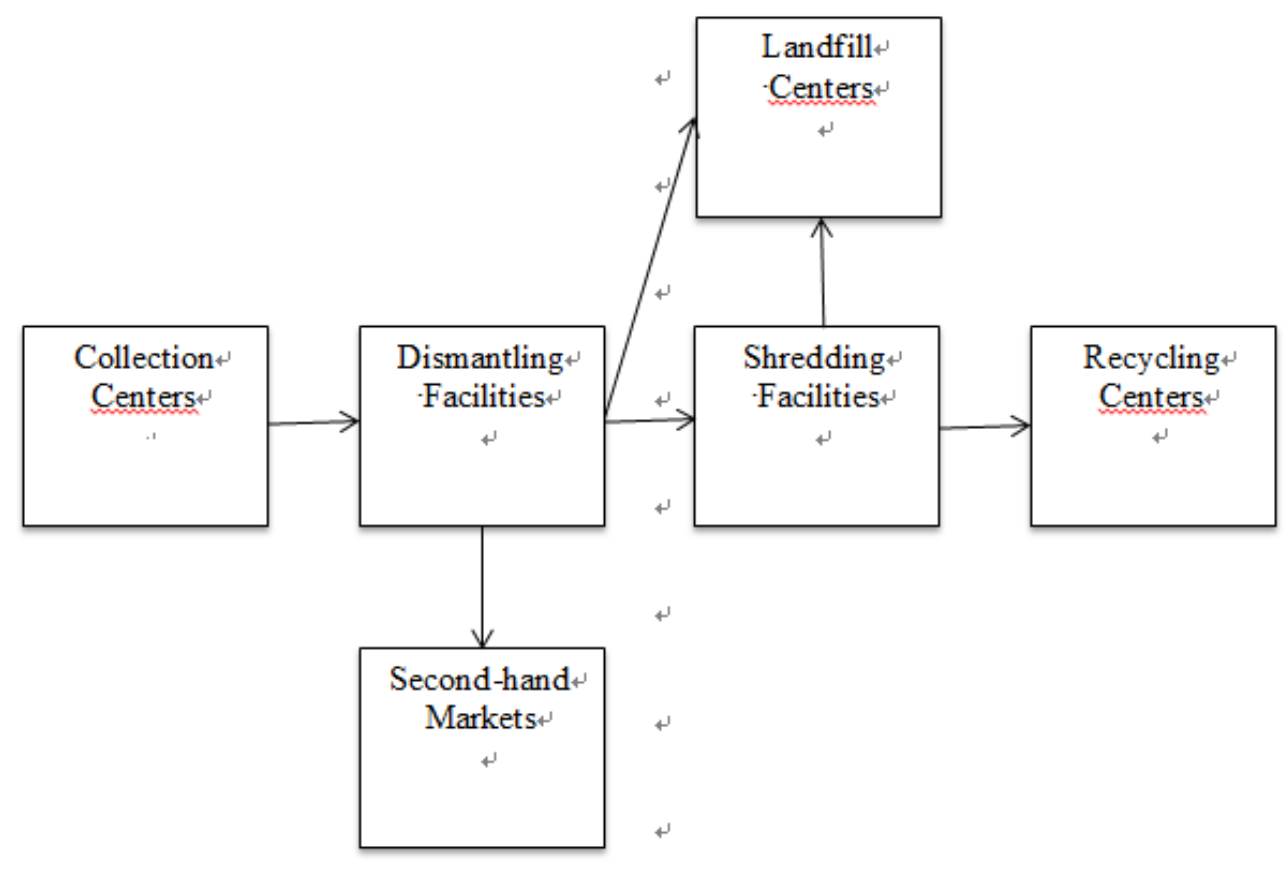

Figure 6. ELV De-manufacturing Network

\subsection{Providing Recommendations in regard to the project}

Recommendations for further study will be discussed after create the model. Implementation of the solution will also be discussed in this particular part of the paper.

\section{Conclusion}

Automotive de-manufacturing systems are important for ensuring sustainability and affordable cost for the newly produced cars. This is because it will lead to an increase in operating standards of the recycling facilities even where there is no full compliance with ELD guidelines. Moreover, it will lead to a control of ELV currently disposed of. In addition, it will lead to the use of recovered as opposed to virgin materials. This is critical in avoiding the environmental impacts arising as a result of production of virgin materials. The model will lead to an idea situation where there will be higher recycling rates which like noted, will be environmentally beneficial for global warming potential. And this is largely due to positive contribution posed by the recycling of ferrous and non-ferrous metals. In addition, when diversions from the landfill are considered, there will be benefits that are even higher. Moreover, the Integrated Life-Cycle Assessment (LCA) and Optimization Approach will considered the system boundaries for each end-of-life option, and these include reuse, recycling, recovery and landfill. The logistics process usually begins from raw materialsto manufacturing, up to the end process at the consumer level. On the contrary, reverse logistics is is a process that begins from dismantling of the equipment before reclamation and recovery. All these processes and activities in reverse logistics systems incur costs and must be included in the design of the system. The project put more emphasis on the different methods and techniques that are known to be effective in developing automotive de-manufacturing systems. 


\section{Future work}

Future work will include the development of the optimization model on a place where end-of-life vehicles' legislations and laws are implemented. It will also be directed to compare between the costs of traditional methods versus de-manufacturing. A sensitivity analysis would be used to understand the overall change in automotive de-manufacturing economics.

\section{References}

Adaptalift Hyster. (2013, May). What is Reverse Logistics. Retrieved from Adaptalift Hyster: http://www.aalhysterforklifts.com.au/index.php/about/blog-post/reverse_logistics_from_oppo rtunity_to_success1

Aljaaidi, W. M., Almohanna, H., \& Zaid Bin Jumah, A. (2013, May). Used Tires Recycling and Utilization in Saudi Arabia. Retrieved October 2014, from http://fac.ksu.edu.sa/sites/default/files/final_repoort_.pdf

Alliance of Automotive Manufacturers. (2010). Automotive Recycling Industry. Retrieved October 2014 , from http://wwwwww.autoalliance.org/download.cfm?downloadfile=1CDF0DE0-B983-11E1-9E4 C000C296BA163\&typename $=$ dmFile $\&$ fieldname $=$ filename

Automotive Recyclers of Canada. (2011, Septemer 20). A National Approach to the Environmental Management of End-of-life Vehicles in Canada. Retrieved 2014, from Automotive Recyclers of Canada: http://autorecyclers.ca/2011/a-national-approach-to-the-environmental-management-of-end-o f-life-vehicles-in-canada/

Autoparts Recycle Association of Australia; Greenfleet; Holden. (2014). Auto Parts Recycling: A Guide to the Future. Retrieved 2014, from Holden: http://www.holden.com.au/resources/documents/recycling_guide.pdf

Autoparts Recycle Association of Australiar; Greenfleet; Holden. (2014). Auto Parts Recycling: A Guide to the Future. Retrieved 2014, from Holden: http://www.holden.com.au/resources/documents/recycling_guide.pdf

BMW Group. (2009, May). Vehicle Recycling: Focusing on Sustainability. Retrieved Jan 2014, from BMW Group: http://www.bmw.com/com/en/owners/service/_shared/pdf/2009_recycling.pdf

$\begin{array}{llll}\text { Ecoamisco. } & \text { (2015). Ecodesign. } & \text { Retrieved }\end{array}$ http://www.amiscocontract.com/Ecoamisco.aspx

Elwany, H., Fors, N., Harraz, N., \& Galal, N. (2007). REVERSE LOGISTICS NETWORK DESIGN: REVIEW OF MODELS AND. 37th International Conference on Computers and Industrial Engineering, 9.

European Commission. (2005, January). Directive 2000/53/EC On End-of-Life Vehicles. 
Retrieved from http://ec.europa.eu/environment/waste/pdf/guidance_doc.pdf

Field, F. R. (1993). The Recycling of Automobiles: Conflicting Environmental Objectives In A Competitive Marketplace. KIET International Seminar on Korea's Auto Industry, A-1 to A-16.

Hatayama, H., Daigo, I., Matsuno, Y., \& Adachi, Y. (2012). Evolution of aluminum recycling initiated by the introduction of next-generation vehicles and scrap sorting technology. Resources, Conservation and Recycling, 8-14. http://dx.doi.org/10.1016/j.resconrec.2012.06.006

Hyflux Ltd. (2007, May). Hyflux, Sedco and Lubrec invest \$45million in first membrane based oil recycling plant in Saudi Arabia. Retrieved from HYflux.listedcompany.com: http://hyflux.listedcompany.com/newsroom/Hyflux_Misc_SEDCO_LUBREC_8May07.pdf

International Specialized Skills Institute. (2009). Vehicle Recycling and Sustainability. Retrieved October 2014, from http://issinstitute.org.au/wp-content/media/2011/05/ISS-FEL-REPORT-N-MCNAMARA-Lo w-Res.pdf

Japan Automobile Manufacturers Association. (2002). New Car Recycling Law in Japan. Retrieved from http://jama-english.jp/europe/news/2002/200209-10uk.pdf

Kanari, N., Pineau, J.-L., \& Shallari, a. S. (2003). End-of-Life Vehicle Recycling in the European Union. Retrieved 2014, from The Minerals, Metals \& Materials Society: http://dx.doi.org/10.1007/s11837-003-0098-7

Mathieux, F., \& Brissaud, D. (2010). End-of-life product-specific material flow analysis. Application to aluminum coming from end-of-life commercial vehicles in Europe. Resources, Conservation and Recycling, 92-105. http://dx.doi.org/10.1016/j.resconrec.2010.07.006

MInistry of Economy, Trade and Industry. (2005). End of Life Vehicle Recycling Law. Retrieved 2014, from MInistry of Economy, Trade and Industry: http://www.meti.go.jp/policy/recycle/main/english/law/end.html

Olson, W. W., \& Sutherland, J. W. (1993). Research Issues in Demanufacuring. Transactions of NAMRI /SME Vol XXI, 443 - 450.

Recycling Today Staff. (2014, March). Middle East Conferences: End of the Road. Retrieved October 2014, from http://www.recyclingtoday.com/middle-east-elv-dubai.aspx

Royal Automotive Club of Victoria. (2014). Vehicle Recycling. Retrieved October 2014, from http://www.racv.com.au/wps/wcm/connect/racv/Internet/Primary/my+car/advice+_+informati on/motoring+_+the+environment/reduce+your+emissions+and+fuel+costs/vehicle+recycling

RSJ Technical Consulting. (2007). What is Korea RoHS. Retrieved 2014, from RSJ technical Consulting: http://www.rsjtechnical.com/WhatisKoreaRoHS.htm

Sanket. (2009). Reverse Logistics. Retrieved from http://www.slideshare.net/sanket_123/reverse-logistics-presentation 


\section{Macrothink}

Environmental Management and Sustainable Development

ISSN 2164-7682 2016, Vol. 5, No. 1

South Korea's waste management policies. (2015). Legislative Secretariat. Retrieved from http://www.legco.gov.hk/yr12-13/english/sec/library/1213inc04-e.pdf

Staudinger, J., \& Keoleian, G. A. (2001, March). Management of End of Life Vehicles in the US. Retrieved 2014, from Center for Sustainable Systems: http://css.snre.umich.edu/css_doc/CSS01-01.pdf

Toyota Motor Corporation. (2014, April). Vehicle Recycling. Retrieved 2014, from Toyota: http://www.toyota-global.com/sustainability/report/vehicle_recycling/

US Environmental Protection Agency. (2012). Automotive Parts. Retrieved from US Environmental Protection Agency: http://www.epa.gov/wastes/conserve/materials/auto.htm

US Environmental Protection Agency. (2014). Automotive Parts. Retrieved from US Environmental Protection Agency: http://www.epa.gov/wastes/conserve/materials/auto.htm

Zarei, M., Mansour, S., Kashan, A.-H., \& Karimi, B. (2010). Designing a Reverse Logistics Network for End-of-Life Vehicles Recovery. Mathematical Problems in Engineering, 16. http://dx.doi.org/10.1155/2010/649028

Zhaoanjian, M., \& Yang, J. (2014, May). Reverse Logistics in Automotive Industry. Retrieved from Hogskolan I Gavle: http://hig.diva-portal.org/smash/get/diva2:725973/FULLTEXT01.pdf

\section{Appendix}

Appendix 1. Parts of vehicles that are Recycled and reused

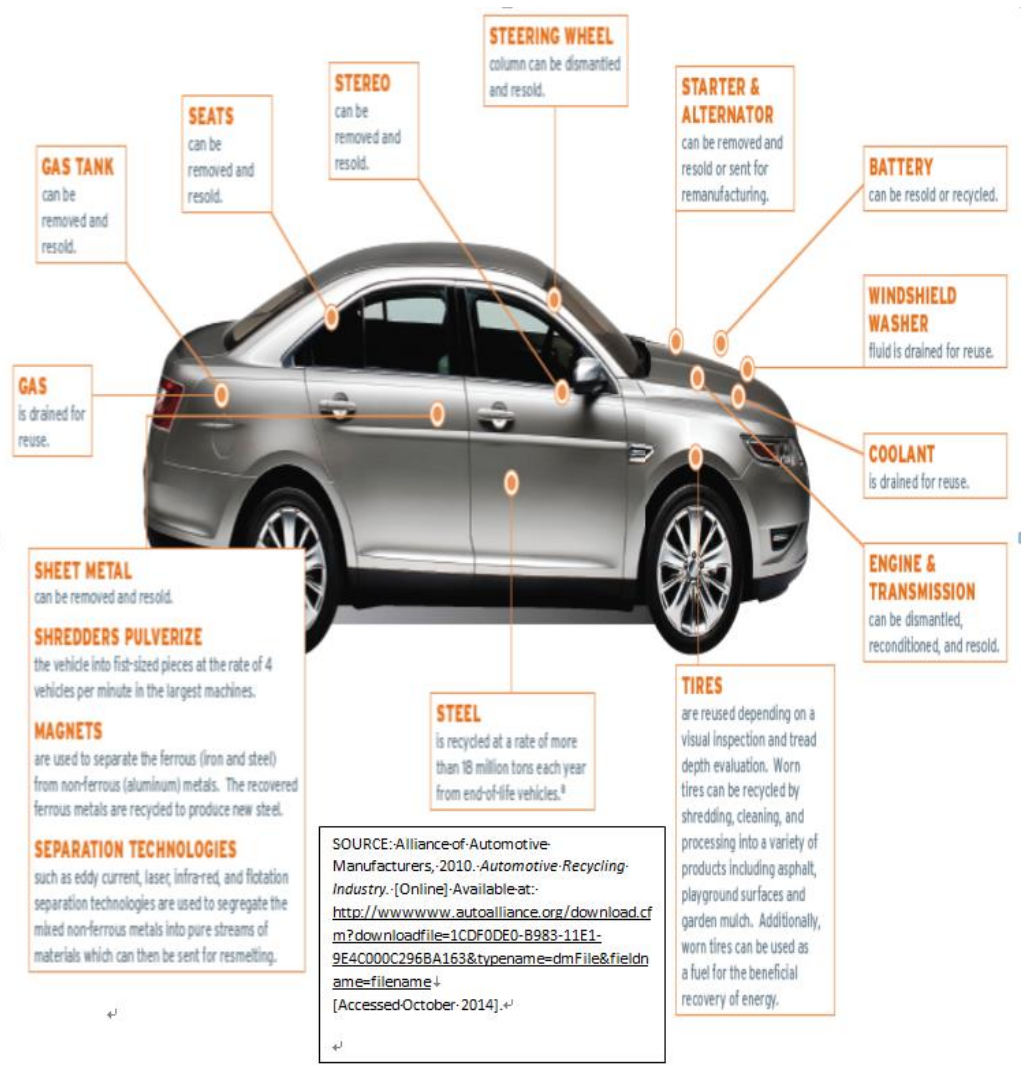


Appendix 2. Dismantled Auto Parts of ELV

SOURCE: (Autoparts Recycle Association of Australiar; Greenfleet; Holden, 2014)

\section{Recycling Auto Parts}

\begin{tabular}{|c|c|c|c|c|c|}
\hline COMPONENT & MATERIALS & DISMANTLING & STORAGE & DISPOSAL & SAFETY \\
\hline Batteries & $\begin{array}{l}\text { Case-plastic or } \\
\text { rubber. } \\
\text { Contents - lead, } \\
\text { sulphuric acid }\end{array}$ & $\begin{array}{l}\text { Remove from } \\
\text { vehicle as } \\
\text { appropriate }\end{array}$ & $\begin{array}{l}\text { Under cover, } \\
\text { off ground storage }\end{array}$ & $\begin{array}{l}\text { For Collection } \\
\text { Contact: } \\
\text { Phone: }\end{array}$ & $\begin{array}{l}\text { Avoid sulphuric acid fumes } \\
\text { or contact with skin. } \\
\text { Gas is explosive - keep } \\
\text { away from ignition sources }\end{array}$ \\
\hline Brake Fluid & $\begin{array}{l}\text { Primarily } \\
\text { diethylene \& } \\
\text { polyethylene } \\
\text { glycol-mono } \\
\text { alkyl ethers }\end{array}$ & $\begin{array}{l}\text { Collected in steel } \\
\text { or plastic drain } \\
\text { pan only used for } \\
\text { that purpose }\end{array}$ & $\begin{array}{l}\text { Under cover, } \\
\text { bunded area, to } \\
\text { appropriate } \\
\text { storage drum or } \\
\text { tank }\end{array}$ & $\begin{array}{l}\text { For Collection } \\
\text { Contact: } \\
\text { Phone: }\end{array}$ & $\begin{array}{l}\text { Corrosive, highly toxic } \\
\text { to environment }\end{array}$ \\
\hline Fuel & $\begin{array}{l}\text { ULP } \\
\text { (unleaded petrol) } \\
\text { LP (leaded petrol) } \\
\text { Diesel }\end{array}$ & $\begin{array}{l}\text { Siphon } \\
\text { mechanically } \\
\text { from tank to } \\
\text { avoid spillage }\end{array}$ & $\begin{array}{l}\text { Under cover } \\
\text { in appropriate } \\
\text { sealed drums }\end{array}$ & $\begin{array}{l}\text { For Collection } \\
\text { Contact: } \\
\text { Phone: }\end{array}$ & $\begin{array}{l}\text { Erect fire hazard waming } \\
\text { signs with approved fire } \\
\text { control equipment at hand. } \\
\text { Avoid fumes }\end{array}$ \\
\hline LPG & $\begin{array}{l}\text { Liquid Petroleum } \\
\text { Gas }\end{array}$ & $\begin{array}{l}\text { Mechanically } \\
\text { decant before tank } \\
\text { is removed from } \\
\text { vehicle }\end{array}$ & $\begin{array}{l}\text { In approved } \\
\text { LPG tanks, in } \\
\text { appropriately } \\
\text { ventilated area }\end{array}$ & $\begin{array}{l}\text { For Collection } \\
\text { Contact: } \\
\text { Phone: }\end{array}$ & $\begin{array}{l}\text { LPG is an explosive } \\
\text { product and is heavier } \\
\text { than air. } \\
\text { Do not allow LPG to } \\
\text { accumulate in low areas }\end{array}$ \\
\hline , & $\begin{array}{l}\text { Engine, } \\
\text { transmission and } \\
\text { differential }\end{array}$ & $\begin{array}{l}\text { Drain to } \\
\text { bulk container in } \\
\text { bunded area. Use } \\
\text { compressed air or } \\
\text { spill free movement } \\
\text { to storage }\end{array}$ & $\begin{array}{l}\text { Under cover, } \\
\text { bunded area, } \\
\text { to appropriate } \\
\text { storage drum or } \\
\text { tank }\end{array}$ & $\begin{array}{l}\text { For Collection } \\
\text { Contact: } \\
\text { Phone: }\end{array}$ & $\begin{array}{l}\text { Appropriate fire hazard } \\
\text { warning sign }\end{array}$ \\
\hline $\begin{array}{l}\text { Air } \\
\text { Conditioning } \\
\text { Gases }\end{array}$ & $\begin{array}{l}\text { R12 Freon, } \\
134 \mathrm{~A} \\
\text { R12 is hazardous } \\
\text { to the } \\
\text { environment }\end{array}$ & $\begin{array}{l}\text { Reclaim by } \\
\text { accredited } \\
\text { operator }\end{array}$ & $\begin{array}{l}\text { To approved } \\
\text { storage containers }\end{array}$ & $\begin{array}{l}\text { For Collection } \\
\text { Contact: } \\
\text { Phone: }\end{array}$ & $\begin{array}{l}\text { Provide safe area for } \\
\text { minimum chance of gas } \\
\text { escapes }\end{array}$ \\
\hline $\begin{array}{c}\text { Air Bag } \\
\text { (undeployed) }\end{array}$ & $\begin{array}{l}\text { Plastics, metals } \\
\text { igniters and } \\
\text { explosives }\end{array}$ & $\begin{array}{l}\text { Removal by } \\
\text { competent } \\
\text { operator }\end{array}$ & $\begin{array}{l}\text { Under cover } \\
\text { secure area. } \\
\text { Must be stored } \\
\text { face up }\end{array}$ & $\begin{array}{l}\text { For Collection } \\
\text { Contact: } \\
\text { Phone: }\end{array}$ & $\begin{array}{l}\text { Handle with care, contains } \\
\text { explosive. Addopt manufacturer's } \\
\text { recommendations for reuse } \\
\text { and general handling. If unit } \\
\text { is scrapped it must be rendered } \\
\text { inoperative by intentionally } \\
\text { deploying or by removing } \\
\text { trigger source }\end{array}$ \\
\hline
\end{tabular}


A Plastics

\begin{tabular}{|c|c|c|c|c|c|}
\hline COMPONENT & MATERIALS & DISMANTLING & STORAGE & DISPOSAL & SAFETY \\
\hline $\begin{array}{c}\text { Bumper } \\
\text { Bar Cover }\end{array}$ & $\begin{array}{l}\text { Various. } \\
\text { Some are } \\
\text { identified for } \\
\text { recycling }\end{array}$ & $\begin{array}{l}\text { Remove from } \\
\text { car where } \\
\text { appropriate }\end{array}$ & $\begin{array}{l}\text { Racked or binned } \\
\text { for recycling }\end{array}$ & $\begin{array}{l}\text { For Collection } \\
\text { Contact: } \\
\text { Phone: }\end{array}$ & $\begin{array}{l}\text { Do not burn. } \\
\text { Fumes are toxic! }\end{array}$ \\
\hline 4 & $\begin{array}{l}\text { Plastic or metal. } \\
\text { Some are } \\
\text { identified for } \\
\text { recycling }\end{array}$ & $\begin{array}{l}\text { Remove from } \\
\text { car where } \\
\text { appropriate }\end{array}$ & $\begin{array}{l}\text { Racked or binned } \\
\text { for recycling }\end{array}$ & $\begin{array}{l}\text { For Collection: } \\
\text { As listed for } \\
\text { other metals } \\
\text { and plastics }\end{array}$ & $\begin{array}{l}\text { Do not burn. } \\
\text { Fumes are toxic! }\end{array}$ \\
\hline $\begin{array}{l}\text { Internal Trim } \\
\text { and Plastic } \\
\text { Fittings }\end{array}$ & $\begin{array}{l}\text { Various. } \\
\text { Some are } \\
\text { identified for } \\
\text { recyeling }\end{array}$ & $\begin{array}{l}\text { Remove from } \\
\text { car where } \\
\text { appropriate }\end{array}$ & $\begin{array}{l}\text { Racked or binned } \\
\text { for recycling }\end{array}$ & $\begin{array}{l}\text { For Collection } \\
\text { Contact: } \\
\text { Phone: }\end{array}$ & $\begin{array}{l}\text { Do not burn. } \\
\text { Fumes are toxic! }\end{array}$ \\
\hline $\begin{array}{l}\text { Plastic } \\
\text { Drums } \\
\text { (empty) }\end{array}$ & $\begin{array}{l}\text { Various. } \\
\text { Some are } \\
\text { identified for } \\
\text { recycling }\end{array}$ & N/A & $\begin{array}{l}\text { Where appropriate. } \\
\text { Contain residues }\end{array}$ & $\begin{array}{l}\text { For Collection } \\
\text { Contact: } \\
\text { Phone: }\end{array}$ & $\begin{array}{l}\text { Do not burn. } \\
\text { Fumes are toxic! } \\
\text { Contain residues }\end{array}$ \\
\hline 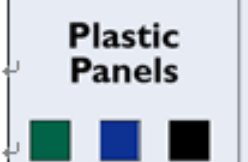 & $\begin{array}{l}\text { Various. } \\
\text { Some are } \\
\text { identified for } \\
\text { recycling }\end{array}$ & $\begin{array}{l}\text { Remove from } \\
\text { car where } \\
\text { appropriate }\end{array}$ & $\begin{array}{l}\text { Racked or binned } \\
\text { for recycling }\end{array}$ & $\begin{array}{l}\text { For Collection } \\
\text { Contact: } \\
\text { Phone: }\end{array}$ & $\begin{array}{l}\text { Do not burn. } \\
\text { Fumes are toxic! }\end{array}$ \\
\hline $\begin{array}{c}\text { Polythene } \\
\text { Film } \\
\text { (packaging) }\end{array}$ & $\begin{array}{l}\text { High Density } \\
\text { Polyethelene } \\
\text { (HDPE) or Low } \\
\text { Density Polyethelene } \\
\text { (LDPE) }\end{array}$ & N/A & Waste bin & $\begin{array}{l}\text { For Collection } \\
\text { Contact: } \\
\text { Phone: }\end{array}$ & $\begin{array}{l}\text { Do not burn. } \\
\text { Fumes are toxic! }\end{array}$ \\
\hline Seats & Various & $\begin{array}{l}\text { Remove from } \\
\text { car where } \\
\text { appropriate }\end{array}$ & $\begin{array}{l}\text { Appropriate } \\
\text { storage }\end{array}$ & $\begin{array}{l}\text { For Collection } \\
\text { Contact: } \\
\text { Phone: }\end{array}$ & $\begin{array}{l}\text { Do not burn. } \\
\text { Fumes are toxic! }\end{array}$ \\
\hline $\begin{array}{c}\text { Trim } \\
\text { Interior \& } \\
\text { Exterior }\end{array}$ & $\begin{array}{l}\text { Various. } \\
\text { Some are } \\
\text { identified for } \\
\text { recycling }\end{array}$ & $\begin{array}{l}\text { Remove from } \\
\text { car where } \\
\text { appropriate }\end{array}$ & $\begin{array}{l}\text { Racked or binned } \\
\text { for recycling }\end{array}$ & $\begin{array}{l}\text { For Collection } \\
\text { Contact: } \\
\text { Phone: }\end{array}$ & $\begin{array}{l}\text { Do not burn. } \\
\text { Fumes are toxic! }\end{array}$ \\
\hline
\end{tabular}




\section{Metals}

\begin{tabular}{|c|c|c|c|c|c|}
\hline COMPONENT & MATERIALS & DISMANTLING & STORAGE & DISPOSAL & SAFETY \\
\hline $\begin{array}{l}\text { Air } \\
\text { Conditioning } \\
\text { Cores }\end{array}$ & $\begin{array}{l}\text { Aluminum, } \\
\text { copper }\end{array}$ & $\begin{array}{l}\text { One piece, using } \\
\text { normal hand tools }\end{array}$ & $\begin{array}{l}\text { Rack or } \\
\text { appropriate bin }\end{array}$ & $\begin{array}{l}\text { For Collection } \\
\text { Contact: } \\
\text { Phone: }\end{array}$ & Handle with gloves \\
\hline $\begin{array}{l}\text { Aluminium \& } \\
\text { Aluminium } \\
\text { Alloys }\end{array}$ & Various types & $\begin{array}{l}\text { Normal hand } \\
\text { tools and } \\
\text { cut-off saws }\end{array}$ & $\begin{array}{l}\text { Rack or } \\
\text { appropriate bin }\end{array}$ & $\begin{array}{l}\text { For Collection } \\
\text { Contact: } \\
\text { Phone: }\end{array}$ & Handle with gloves \\
\hline um & $\begin{array}{l}\text { Wheel rims and } \\
\text { other mechanical } \\
\text { components }\end{array}$ & $\begin{array}{l}\text { Normal hand } \\
\text { tools }\end{array}$ & $\begin{array}{l}\text { Rack or } \\
\text { appropriate bin }\end{array}$ & $\begin{array}{l}\text { For Collection } \\
\text { Contact: } \\
\text { Phone: }\end{array}$ & $\begin{array}{l}\text { Warning! Fire hazard } \\
\text { and gives off toxic fumes } \\
\text { when burned. } \\
\text { Avoid cut-off saws and } \\
\text { oxy-acetylene equipment }\end{array}$ \\
\hline $\begin{array}{l}\text { Sodies } \\
\text { anels } \\
\square\end{array}$ & Steel and plastics & $\begin{array}{l}\text { Normal hand tools } \\
\text { and cut-off saws } \\
\text { where appropriate }\end{array}$ & $\begin{array}{l}\text { Rack or stack } \\
\text { safely in a secure } \\
\text { area }\end{array}$ & $\begin{array}{l}\text { For Collection } \\
\text { Contact: } \\
\text { Phone: }\end{array}$ & $\begin{array}{l}\text { Use of oxy-acetylene to a } \\
\text { minimum, may ignite } \\
\text { plastics, rubber, grease } \\
\text { which produces dense black } \\
\text { fumes detrimental to health } \\
\text { and air quality }\end{array}$ \\
\hline $\begin{array}{c}\text { Catalytic } \\
\text { Converters }\end{array}$ & $\begin{array}{l}\text { Contain toxic } \\
\text { heavy metals. } \\
\text { Only active } \\
\text { when hot }\end{array}$ & $\begin{array}{l}\text { Normal hand tools } \\
\text { or cut-off saw to } \\
\text { adjacent pipes }\end{array}$ & $\begin{array}{l}\text { Rack or } \\
\text { appropriate bin }\end{array}$ & $\begin{array}{l}\text { For Collection } \\
\text { Contact: } \\
\text { Phone: }\end{array}$ & $\begin{array}{l}\text { Avoid heat } \\
\text { e.g. The use of } \\
\text { oxy-acetylene equipment }\end{array}$ \\
\hline 4 & $\begin{array}{l}\text { Radiators, } \\
\text { heater cores } \\
\text { and electrical } \\
\text { wiring etc }\end{array}$ & $\begin{array}{l}\text { Normal hand tools } \\
\text { and cut-off saws }\end{array}$ & $\begin{array}{l}\text { Rack or } \\
\text { appropriate bin }\end{array}$ & $\begin{array}{l}\text { For Collection } \\
\text { Contact: } \\
\text { Phone: }\end{array}$ & $\begin{array}{l}\text { Handle with gloves. } \\
\text { Do not burn electrical } \\
\text { wiring insulation. } \\
\text { Fumes are toxic }\end{array}$ \\
\hline 4 & Steel & $\begin{array}{l}\text { Appropriate } \\
\text { handling } \\
\text { equipment }\end{array}$ & $\begin{array}{l}\text { In bays with lids } \\
\text { securely in place. } \\
\text { Bund area to } \\
\text { contain residues }\end{array}$ & $\begin{array}{l}\text { For Collection } \\
\text { Contact: } \\
\text { Phone: }\end{array}$ & $\begin{array}{l}\text { Possible hazardous fumes } \\
\text { and explosive potential. } \\
\text { Contain residues }\end{array}$ \\
\hline $\begin{array}{l}\text { Oil Filters } \\
\text { (drained) }\end{array}$ & $\begin{array}{l}\text { Steel, paper } \\
\text { and fibres }\end{array}$ & $\begin{array}{l}\text { Use normal } \\
\text { hand tools. } \\
\text { Contain any } \\
\text { residues }\end{array}$ & $\begin{array}{l}\text { In leak-proof } \\
\text { drums to } \\
\text { contain residues }\end{array}$ & $\begin{array}{l}\text { For Collection } \\
\text { Contact: } \\
\text { Phone: }\end{array}$ & Contain residues \\
\hline
\end{tabular}




\section{Macrothink}

Environmental Management and Sustainable Development

ISSN 2164-7682

2016, Vol. 5, No. 1

Metals

\begin{tabular}{|c|l|l|l|l|l|}
\hline COMPONENT & MATERIALS & DISMANTLING & STORAGE & \multicolumn{1}{|c|}{ DISPOSAL } & \multicolumn{1}{|l|}{ SAFETY } \\
\hline Radiators & $\begin{array}{l}\text { Copper, aluminum } \\
\text { and plastic }\end{array}$ & $\begin{array}{l}\text { Remove to contain } \\
\text { coolant residues, } \\
\text { using normal } \\
\text { hand tools }\end{array}$ & $\begin{array}{l}\text { Bund area to } \\
\text { contain coolant } \\
\text { residues }\end{array}$ & $\begin{array}{l}\text { For Collection } \\
\text { Contact: }\end{array}$ & $\begin{array}{l}\text { Warning sign! Radiator } \\
\text { coolant is toxic to } \\
\text { environment, especially } \\
\text { waterways. } \\
\text { Handle with gloves }\end{array}$ \\
\hline $\begin{array}{l}\text { Steel and } \\
\text { Steel Alloys }\end{array}$ & $\begin{array}{l}\text { Steel and } \\
\text { steel alloys }\end{array}$ & $\begin{array}{l}\text { Normal hand tools } \\
\text { and cut-off saws, } \\
\text { in preference to } \\
\text { oxy-acetylene } \\
\text { cutting }\end{array}$ & $\begin{array}{l}\text { Rack or } \\
\text { appropriate bin }\end{array}$ & For Collection \\
\hline Contact: & Phone: & Handle with gloves \\
\hline
\end{tabular}

\section{Liquids}

\begin{tabular}{|c|c|c|c|c|c|}
\hline Coolant & $\begin{array}{l}\text { Includes } \\
\text { phosphoric acid, } \\
\text { hydrazine, } \\
\text { ethylene glycol } \\
\text { and alcohols }\end{array}$ & $\begin{array}{l}\text { Collect in } \\
\text { bunded spill } \\
\text { containment area }\end{array}$ & $\begin{array}{l}\text { Transfer to } \\
\text { appropriate } \\
\text { storage drums in } \\
\text { bunded area }\end{array}$ & $\begin{array}{l}\text { For Collection } \\
\text { Contact: } \\
\text { Phone: }\end{array}$ & $\begin{array}{l}\text { Waming sign! } \\
\text { Radiator coolant is toxic } \\
\text { to environment, } \\
\text { especially waterways }\end{array}$ \\
\hline $\begin{array}{l}\text { Interceptor } \\
\text { Waste and } \\
\text { Oil Separator } \\
\text { Waste }\end{array}$ & $\begin{array}{l}\text { Oils, grease, } \\
\text { water, chemicals, } \\
\text { detergent and } \\
\text { sludge }\end{array}$ & $\begin{array}{l}\text { Pump to dedicated } \\
\text { holding tank }\end{array}$ & $\begin{array}{l}\text { Pumped to } \\
\text { dedicated holding } \\
\text { tank in bunded } \\
\text { area for removal } \\
\text { by contractor }\end{array}$ & $\begin{array}{l}\text { For Collection } \\
\text { Contact: } \\
\text { Phone: }\end{array}$ & $\begin{array}{l}\text { Warning sign! } \\
\text { Hazardous Waste! }\end{array}$ \\
\hline $\begin{array}{l}\text { Caustic } \\
\text { Cleaning } \\
\text { Solutions }\end{array}$ & $\begin{array}{l}\text { Caustic Soda } \\
\text { (usually hot tank } \\
\text { application) }\end{array}$ & $\begin{array}{l}\text { When cool, } \\
\text { transfer to storage } \\
\text { in bunded spill } \\
\text { containment area }\end{array}$ & $\begin{array}{l}\text { Under cover, } \\
\text { bunded area to } \\
\text { appropriate } \\
\text { storage drum } \\
\text { or tank }\end{array}$ & $\begin{array}{l}\text { For Collection } \\
\text { Contact: } \\
\text { Phone: }\end{array}$ & $\begin{array}{l}\text { Warning sign! } \\
\text { Corrosive - highly toxic } \\
\text { to environment }\end{array}$ \\
\hline Solvents & $\begin{array}{l}\text { Oil and grease } \\
\text { removal, general } \\
\text { parts cleaning }\end{array}$ & $\begin{array}{l}\text { Drain into } \\
\text { dedicated container } \\
\text { in bunded spill } \\
\text { containment area }\end{array}$ & $\begin{array}{l}\text { Under cover in } \\
\text { dedicated } \\
\text { container for } \\
\text { collection by } \\
\text { contractor }\end{array}$ & $\begin{array}{l}\text { For Collection } \\
\text { Contact: } \\
\text { Phone: }\end{array}$ & $\begin{array}{l}\text { Appropriate fire hazard } \\
\text { warning sign. } \\
\text { 'Hazardous Chemical' sign }\end{array}$ \\
\hline
\end{tabular}

\section{Tyres}

\begin{tabular}{|l|l|l|l|l|l|}
\hline COMPONENT & MATERIALS & DISMANTLING & STORAGE & DISPOSAL & \multicolumn{1}{|c|}{ SAFETY } \\
\hline \multicolumn{1}{|c|}{ Tyres } & $\begin{array}{l}\text { Rubber, steel } \\
\text { and fabrics }\end{array}$ & $\begin{array}{l}\text { Remove as } \\
\text { appropriate }\end{array}$ & $\begin{array}{l}\text { Fenced area. } \\
\text { Check maximum } \\
\text { permissible } \\
\text { storage numbers. } \\
\text { See local } \\
\text { authorities }\end{array}$ & $\begin{array}{l}\text { For Collection } \\
\text { Contact: }\end{array}$ & $\begin{array}{l}\text { Ensure minimum } \\
\text { quantities stored. } \\
\text { Keep away from } \\
\text { ignition sources }\end{array}$ \\
\hline $\begin{array}{l}\text { Inner Tubes } \\
\text { and Rubber } \\
\text { Components }\end{array}$ & $\begin{array}{l}\text { Rubber, hoses, } \\
\text { mounts etc }\end{array}$ & $\begin{array}{l}\text { Remove as } \\
\text { appropriate }\end{array}$ & $\begin{array}{l}\text { Collection bin as } \\
\text { appropriate }\end{array}$ & For Collection & Contact: \\
\hline
\end{tabular}




\section{Hazardous Materials (other than liquid)}

\begin{tabular}{|c|c|c|c|c|c|}
\hline $\begin{array}{l}\text { Adhesives, Gasket } \\
\text { O-Rings \& Seals } \\
\text { including } \\
\text { Flüoroelastoma } \\
\text { Sealants used } \\
\text { between panels } \\
\text { e.g.Viton }\end{array}$ & $\begin{array}{l}\text { Fire wall to body } \\
\text { adhesives, etc } \\
\text { Extremely } \\
\text { dangerous to skin } \\
\text { when hot }\end{array}$ & $\begin{array}{l}\text { Keep away from } \\
\text { oxy-acetylene } \\
\text { flame or any other } \\
\text { heat source }\end{array}$ & $\begin{array}{l}\text { Leave intact where } \\
\text { possible as on } \\
\text { fire wall etc }\end{array}$ & $\begin{array}{l}\text { For Collection } \\
\text { Contact: } \\
\text { Phone: }\end{array}$ & $\begin{array}{l}\text { Extremely dangerous to skin } \\
\text { when hot: Clear liquid } \\
\text { hydrofluoric acid forms on } \\
\text { top of burned components. } \\
\text { Clean with detergent } \\
\text { solution and use heavy duty } \\
\text { neoprene gloves }\end{array}$ \\
\hline
\end{tabular}

\section{Other Wastes}

\begin{tabular}{|c|c|c|c|c|c|}
\hline COMPONENT & MATERIALS & DISMANTLING & STORAGE & DISPOSAL & SAFETY \\
\hline $\begin{array}{c}\text { Overalls, } \\
\text { Gloves and } \\
\text { Cleaning Rags }\end{array}$ & $\begin{array}{l}\text { Cotton } \\
\text { polyester/leather. } \\
\text { Oil impregnated }\end{array}$ & $\mathrm{N} / \mathrm{A}$ & $\begin{array}{l}\text { Under cover to } \\
\text { dedicated storage } \\
\text { for waste } \\
\text { collection or } \\
\text { cleaning }\end{array}$ & $\begin{array}{l}\text { For Collection } \\
\text { Contact: } \\
\text { Phone: }\end{array}$ & $\begin{array}{l}\text { Keep away from } \\
\text { ignition sources }\end{array}$ \\
\hline $\begin{array}{l}\text { Paper and } \\
\text { Cardboard }\end{array}$ & $\begin{array}{l}\text { Packaging and } \\
\text { newspapers }\end{array}$ & $\begin{array}{l}\text { Package in } \\
\text { manageable piles }\end{array}$ & Under cover & $\begin{array}{l}\text { For Collection } \\
\text { Contact: } \\
\text { Phone: }\end{array}$ & $\begin{array}{l}\text { Keep away from } \\
\text { ignition sources }\end{array}$ \\
\hline $\begin{array}{l}\text { Windscreen } \\
\text { and Side } \\
\text { Glass }\end{array}$ & $\begin{array}{l}\text { Safety glass. } \\
\text { (This can be used } \\
\text { as asphalt filler). } \\
\text { Laminated Glass }\end{array}$ & $\begin{array}{l}\text { Remove as } \\
\text { appropriate }\end{array}$ & $\begin{array}{l}\text { In dedicated bin } \\
\text { or racks }\end{array}$ & $\begin{array}{l}\text { For Collection } \\
\text { Contact: } \\
\text { Phone: }\end{array}$ & Handle with care \\
\hline
\end{tabular}

\section{Copyright Disclaimer}

Copyright for this article is retained by the author(s), with first publication rights granted to the journal.

This is an open-access article distributed under the terms and conditions of the Creative Commons Attribution license (http://creativecommons.org/licenses/by/3.0/). 